\title{
Fellowship for wife of Romanian President
}

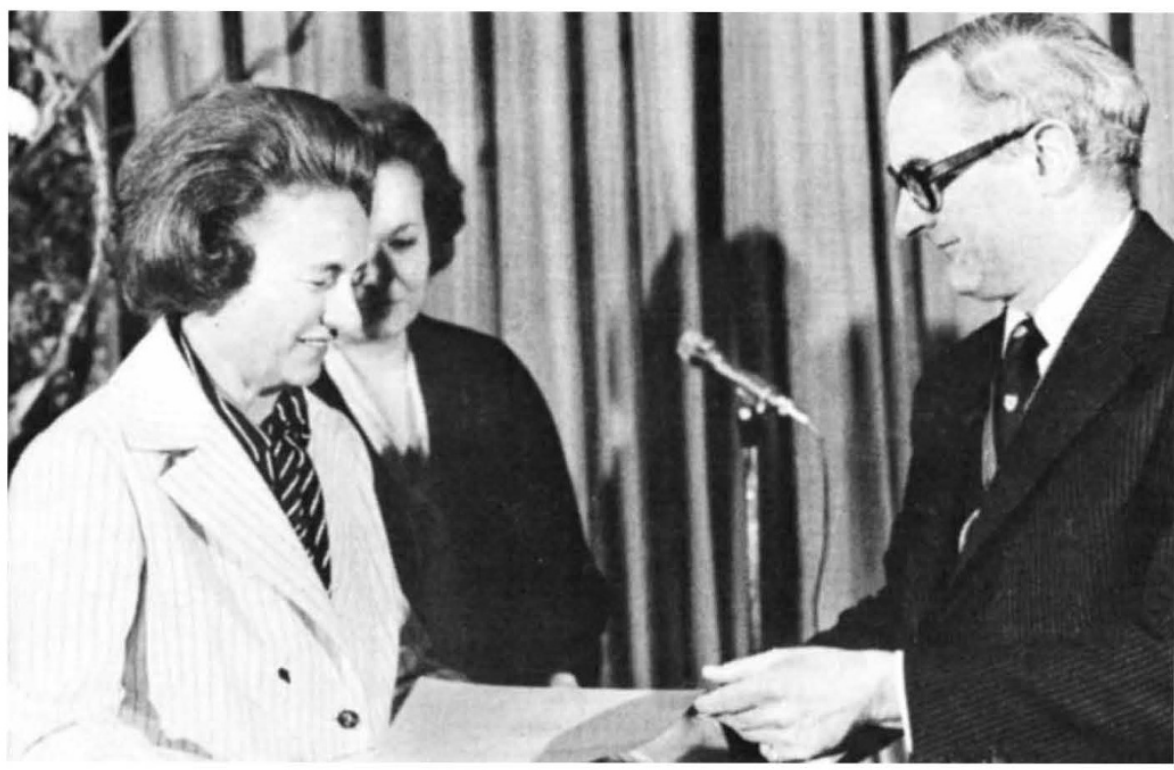

LAST week's state visit to Britain of President Nicolae Ceausescu, of Romania, and his wife was exceptional in its scientific implications-for Dr Elena Ceausescu is a scientist in her own right and, as Director-General of the Central Institute for Chemical Research in Bucharest, responsible for all research and development activities in chemistry in Romania and the implementation of new technology in the Romanian chemical industry.

The inauguration of Dr Ceausescu as a Fellow of the Royal Institute of Chemistry was not, therefore, simply a formal honour paid to a visiting VIP. (Had that been the case, she could have been created an Honorary Fellow). Dr Ceausescu applied for Fellowship in the regular manner, submitting her published research on macromolecular compounds, and the chemistry of polymers and rubber. Certainly, it would be idle to pretend that the ceremony of inauguration was arranged without reference to her husband's position--not all new Fellows are escorted to the Institute by a party of diplomatic personnel-nor do they merit a champagne reception afterwards. Within the framework of diplomatic procedure, however, Dr Ceausescu's speech was that of a scientist rather than of the wife of a head of state. Even her remarks on peace and disarmament were framed in a scientific rather than a political context-referring to the vast expenditure of "scientific potential ... for the manufacture of means of mass destruction", and the deep interest of scientists "that the fruit of their work serve the welfare and happiness of the peoples and not destruction and war".

In his speech of welcome, the Presi- dent of the Institute, Professor R. O. C. Norman noted that so far "our links with chemists in Romania have not been close". Dr Ceausescu replied: "Personally I consider that the distinctions with which you have honoured me today oblige me to work for the strengthening of RomanianBritish collaboration in the field of science in general and in that of chemical research in particular".

In fact, a number of exchange agreements already do exist. There has been an Romania-British intergovernmental agreement in existence since 1967, and a long-standing cooperation agreement between the Romanian Academy of Sciences and the Royal Society. Several technology agreements have already been signed in connection with the visit, and a number more are expected in its aftermath.

What, however, are the prospects for joint research under such agreements? According to an official publication of the Romanian National Council for Science and Technology (a body charged in law with "ensuring fulfilment of party and state policy in science and technology" and directly subordinated to the Central Committee of the Romanian Communist Party and the Council of Ministers) Romanian science is highly target-orientated. $\mathrm{R}$ and $\mathrm{D}$ is organised on the basis of economic self-sufficiency and financed, in the case of short-term projects, by contracts with industry. In the case of research where the pay-off point must be estimated in terms of decades, and also inter-disciplinary research projects, the research may be supported from the state budget directly-but this, too, is on a contractual basis.

What then of basic research and serendipity? Are they not, at least to some extent, disregarded by the planners? Not according to one scientific spokesperson, who stressed, however, that he was speaking entirely unofficially. He told Nature that basic research also had an important part to play, but that one must understand the underlying philosophy behind Romanian science policy. In the past, he said, Romanian science had been strong on the theoretical side, but there had been a failure in implementation. What was needed now was an expansion of applied science, to match the rapid expansion of Romanian industry.

Speaking of the various agreements signed in connection with the state visit, he noted that the Ministerial cooperation agreement on transport would cover quite a considerable amount of what might at first glance appear to be basic research, ranging from the mathematical modelling of traffic flows and optimisation problems (applied to containerisation) to environmental pollution and even sociology. A similar Ministerial agreement on agriculture, he said, would cover the stimulation of seed, storage of crops, and the logistics of fertiliser application.

Clearly, in any programme of mutual cooperation, both sides must make concessions to the "research philosophy" of the other. To British scientists, the Romanian statute that (according to Decree 689/1973 and Law No. 21/1974) scientific research staff including heads of sectors and laboratories are periodically "recertified according to their positions and their contributions" in order to maintain "dynamic performance" must seem more than a little alarming. Doubtless such "recertification" periodically eliminates much academic dead wood, but what of the unfortunate scientist who fails to arrive at even a negative result in the stipulated time? The spokesperson explained that it is not simply research results which are taken into account, but personal publications, keenness in keeping up one's reading and awareness of current trends, and general demeanour and approach.

British scientists who take part in future joint ventures with their Romanian counterparts should therefore be assured that the latter will have a lively and active part to play and that such agreements, like $\mathrm{Dr}$ Ceausescu's admission to the Royal Institute of Chemistry, will represent more than diplomatic lip-service to the ideals of scientific exchange.

Vera Rich 